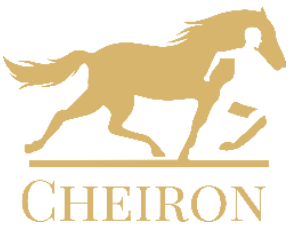

Cheiron: The International Journal of

Equine and Equestrian History

Vol. 1, Issue 1/2021

(C) The Authors 2021

Available online at

http://trivent-publishing.eu/

\title{
Arabians in the Architecture: Historiographic Implications of Misidentification
}

\author{
Miriam A Bibby
}

\begin{abstract}
The Arabian, or more correctly, Arab horse, is widely acknowledged to be one of the most influential horse breeds in the world. Enthusiasts of the breed admire its beauty and its quality of endurance. They also frequently claim it has a long and influential bistory, some suggesting this dates back to the days of the kings of Egypt, if not beyond. It is the historiographical aspect with which this paper intends to engage, arguing that some key examples currently identified as Arab(ian) horses are not Arabs at all. This has created long-standing issues with the literature on the breed and its history, as well as affecting our understanding of the origins of other breeds.
\end{abstract}

\section{Keywords}

Arabian horse; Arab horse; Wilfrid Blunt; Anne Blunt; Crabbet Stud; James Cossar Ewart; Newstead; Thoroughbred; equine taxonomy; Scotland; Shakespeare; Venus and Adonis.

DOI: 10.22618/TP.Cheiron.20211.1.233007

CHEIRON is published by Trivent Publishing

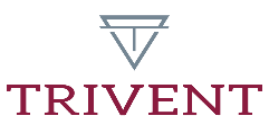

This is an Open Access article distributed in accordance with the Creative Commons Attribution Non Commercial (CC$B Y-N C$-ND 4.0) license, which permits others to copy or share the article, provided original work is properly cited and that this is not done for commercial purposes. Users may not remix, transform, or build upon the material and may not distribute the modified material (bttp:/ / creativecommons.org/licenses/by-nc/4.0/) 


\title{
Arabians in the Architecture: Historiographic Implications of Misidentification
}

\author{
Miriam A Bibby ${ }^{1}$
}

\begin{abstract}
The Arabian, or more correctly, Arab horse, is widely acknowledged to be one of the most influential horse breeds in the world. Enthusiasts of the breed admire its beauty and its quality of endurance. They also frequently claim it has a long and influential history, some suggesting this dates back to the days of the kings of Egypt, if not beyond. It is the historiographical aspect with which this paper intends to engage, arguing that some key examples currently identified as Arab(ian) horses are not Arabs at all. This has created long-standing issues with the literature on the breed and its history, as well as affecting our understanding of the origins of other breeds.
\end{abstract}

\section{Keywords}

Arabian horse; Arab horse; Wilfrid Blunt; Anne Blunt; Crabbet Stud; James Cossar Ewart; Newstead; Thoroughbred; equine taxonomy; Scotland; Shakespeare; Venus and Adonis

\section{Introduction: Issues of Orientalist discourse}

Throughout this paper it will be argued that a desire to recognize Arab(ian) horses and establish their antiquity and purity has led to major issues of identification in artistic, literary, and scientific works. This myth of the Arabian influence continues to cause issues today. DNA research indicates that the modern Arabian horse in Europe, with its instantly recognisable phenotype, has only emerged within the last two centuries, ${ }^{2}$ and also that the widely held belief that it is the most important contributor to the Thoroughbred is incorrect. ${ }^{3}$ Despite this knowledge being now available, claims of influence, superiority and great antiquity are still made for the breed, although these are increasingly interrogated. A recent publication by Delpeut and Hettema ${ }^{4}$ engaged admirably with the presumed identification of

\footnotetext{
${ }^{1}$ School of Interdisciplinary Studies, University of Glasgow.

2 I Głażewska, 'Speculations on the Origin of the Arabian Horse Breed' in Livestock Science 129 (1)2010, 49-55.

${ }^{3}$ Elissa J. Cosgrove, Raheleh Sadeghi, Florencia Schlamp, Heather M. Holl, Mohammad MoradiShahrbabak, Seyed Reza Miraei-Ashtiani, Salma Abdalla, Ben Shykind, Mats Troedsson, Monika Stefaniuk-Szmukier, Anil Prabhu, Stefania Bucca, Monika Bugno-Poniewierska, Barbara Wallner, Joel Malek, Donald C. Miller, Andrew G. Clark, Douglas F. Antczak \& Samantha A. Brooks, "Genome Diversity and the Origin of the Arabian Horse," in Scientific Reports (2020) 10:9702 https://doi.org/10.1038/s41598-020-66232-1.

${ }^{4}$ Lonneke Delpeut and Hylke Hettema, "Ancient Arabian horses? Revisiting ancient Egyptian equine imagery" in Current Research in Egyptology 2019: Proceedings of the Twentieth Annual Symposium, ed. Marta Arranz Cárcamo, Raúl Sánchez Casado, Albert Planelles Orozco, Sergio Alarcón Robledo, Jónatan Ortiz García, Patricia Mora Riudavets (Oxford: Archaeopress Publishing, 2021), 168 - 182.
} 
Arabian horses, or "proto-Arabians," in ancient Egyptian art, and serves as a useful introduction to some of the issues. Citing research from scholars active in the field of DNA analysis such as Głażewska, and of anthropology, such as Lange, ${ }^{5}$ in addition to their own investigations, the researchers conclude that "the predominantly orientalist discourse about the history of Arabian horses has overshadowed the actual reality of the identity of the Egyptian horse."6

Individual horses, as well as whole breeds, have also been overshadowed by Orientalist discourse that promotes the Arabian above all other breeds for antiquity and purity. This paper draws on two visual examples, as well as one literary, and one archaeological, example to make its case.

\section{Orientalist influence: two visual examples}

\section{A. Miss Neasham}

The first is the image of the early racehorse named Miss Neasham, sometimes Mother Neasham, bred in Yorkshire, whose massive portraits (one is 8 feet/3.15 meters high) hang in Temple Newsam Hall in Leeds (Fig. 1 and 2). The portraits were painted ca. 1727, therefore still at a relatively early stage of the development of the Thoroughbred racehorse, which was produced from a genetic mix of various horse phenotypes and landraces, including the Hobby and Galloway (which DNA indicates was the source of the speed gene ${ }^{7}$ ), Barb, Turkoman, and Arabian (of which, as Nash notes, there were very few in the country during this period ${ }^{8}$ ). Indeed, DNA research within the past twenty years has shown that the contribution of the Arabian horse to the Thoroughbred is not significant, and that as well as the contribution from Galloways and Hobbies, the other major contribution came from the Turkoman. ${ }^{9}$ It should be noted that the Barb was also particularly influential on early racing in the sixteenth century, with a gift of Barb mares provided to Henry VIII by the Gonzagas of Mantua. ${ }^{10}$

Miss Neasham is referenced in Jack Fairfax-Blakeborough's Northern Turf History Volume III in connection with one of her offspring, Miss Patty, who was clearly categorised as a racing galloway, since Fairfax-Blakeborough comments:

As an instance of the merits and value of some of these galloways, Mr.

Darley's chestnut mare Miss Patty (by Skipjack) was good enough to compete

in the 1737 Royal Guineas at Hambleton - one of the most important races

\footnotetext{
${ }^{5}$ Cristoph Lange, "The Making and Remaking of the Arabian Horse-From the Arab Bedouin Horse to the Modern Straight Egyptian" in Horse Breeds and Human Society: Purity, Identity and the making of the Modern Horse, eds. Monica. Mattfield and Kristen Guest (London: Routledge, 2020), 234-50.

${ }^{6}$ Delpeut and Hettema, "Ancient Arabian Horses," 180.

${ }^{7}$ M. A. Bower, M. G. Campana, M. Whitten, C. J. Edwards, H. Jones, E. Barrett, R. Cassidy, R. E. R. Nisbet, E. W. Hill, C. J. Howe, and M. Binns, "The cosmopolitan maternal heritage of the Thoroughbred racehorse breed shows a significant contribution from British and Irish native mares," Biol. Lett. 7 (2011): 316-320.

${ }^{8}$ Richard Nash, "'Honest English Breed': the Thoroughbred as Cultural Metaphor" in The Culture of the Horse: Status, Discipline and Identity in the Early Modern World, ed. Karen Raber and Treva Tucker (New York and London: Palgrave Macmillan, 2005), 250.

${ }^{9}$ Cosgrove et al, "Genome Diversity and the Origin of the Arabian Horse," https://doi.org/10.1038/ s41598-020-66232-1.

10 Carlo Cavriani, Le razze Gonzaghesche di cavalli nel Mantovano e la loro influenza sul pure sangue inglese in the series Rassegna Contemporanea, anno II, 3:4 (1909): 23-24; Andrea Tonni, "The Renaissance Studs of the Gonzagas of Mantua" in The Horse as Cultural Icon: The Real and the Symbolic Horse in the Early Modern World, eds. Peter Edwards, Karl A.E. Enenkel and Elspeth Graham (Leiden: Brill, 2012), 274-276.
} 
of the day at this time. She was out of a well-bred mare, Miss Neasham, and was foaled 1733. Next year Miss Neasham was put back into training and won several plates as Mother Neasham. [...] Miss Patty was the grandame of MacHeath, whose performance in the summer of 1778 (according to Pick's York Racing Calendar) 'are not equalled in the annals of the Turf, for he swept that year all the four-year-old plates in the counties of Lancashire and Cheshire...' [...] Many other instances could be cited of animals which ran in apparently insignificant $£ 20$ Galloway Plates and later left their mark in the Stud Book. ${ }^{11}$

The images of Miss Neasham, and the contemporary portrait of the chestnut racehorse Aleppo at Temple Newsam, which looks very similar, are therefore important artistic works for research relating to the appearance of early Thoroughbred racehorses. Of Miss Neasham, John Fairley, author of two books on the subject of horses in art, ${ }^{12}$ writes:

The painting of Miss Neasham stands eight feet high. She was by Hartley's Blind Barb, another stallion imported from the East, and has what would be regarded today as a very Arab head, small and bright-eyed. The Arab tail stands out, and her lean, compact body is well set on at the shoulder. ${ }^{13}$

It is very doubtful whether, looking at the portraits, the majority of modern Arabian horse enthusiasts would agree with Fairley's conclusion. Moreover, a Barb and an Arab are not the same thing, and this highlights the ongoing issue with the terms "Oriental" or "Eastern" horses, and the interchangeability of the terms Arab(ian), Barb and Turk(oman). Fairley's clear desire to see the influence of the Arab in Miss Neasham not only stretches credibility, it serves as a good example of how Orientalist discourse, and the focus on the Arab horse in particular, overshadows the contribution of other breeds and types in the creation of the Thoroughbred. Fairley notes that her sire is described as a Barb, not an Arabian; there is no justification for crediting her with being an Arabian at all.

Miss (or Mother) Neasham is well enough documented. The closest she came to being an Arab was that she was in the stable of the famous Darley of Yorkshire, to whom the Darley Arabian belonged. Lawrence describes her as

This famous racer and brood-mare... her shoulder formed like the hare, of great width at the summit $[\ldots]$ ran with her fore-legs as wide as a barn door. Her shoulders, however thick, declined deeply into her waist, adding to her strength without diminishing her powers of progression. She was bred at Neesham, in Cumberland, foaled in 1720, and sold to Mr. Darley of Yorkshire. Got by Hartley's blind Horse, son of the Holderness Turk, out of the dam of Favourite, by Commoner, son of Place's White Turk. She was of the oldest blood then in England. ${ }^{14}$

If anything, Miss/Mother Neasham favours that other famous Yorkshire horse breed, the Cleveland Bay, which, along with the Thoroughbred, claims descent from the Darley Arabian, a horse which many scholars consider is Turkoman in type. However, she did not descend from the Darley line. She was first called by the unpromising name of Cripple, and the fact

\footnotetext{
${ }^{11}$ Jack Fairfax-Blakeborough, Northern Turf History Vol III (London: J.A. Allen, 1950), 59-60.

12 John Fairley, The Art of the Horse (New York: Abbeville, 1995); John Fairley, Racing in Art (London: John Murray, 1990).

13 Fairley, The Horse in Art, 72. It should be noted that the image he uses is reversed.

${ }^{14}$ John Lawrence, History and Delineation of the Horse (London: Albion Press, 1809), 269.
} 
that she was a grand-daughter of Place's White Turk is significant. This last horse, Nash suggests, was the horse acquired by Oliver Cromwell from Sultan Mohammed IV and was possibly an Arabian/Turkoman cross. ${ }^{15}$ Both Nash and Mackay-Smith believe the influence of this stallion has been underrepresented in documentation. ${ }^{16}$

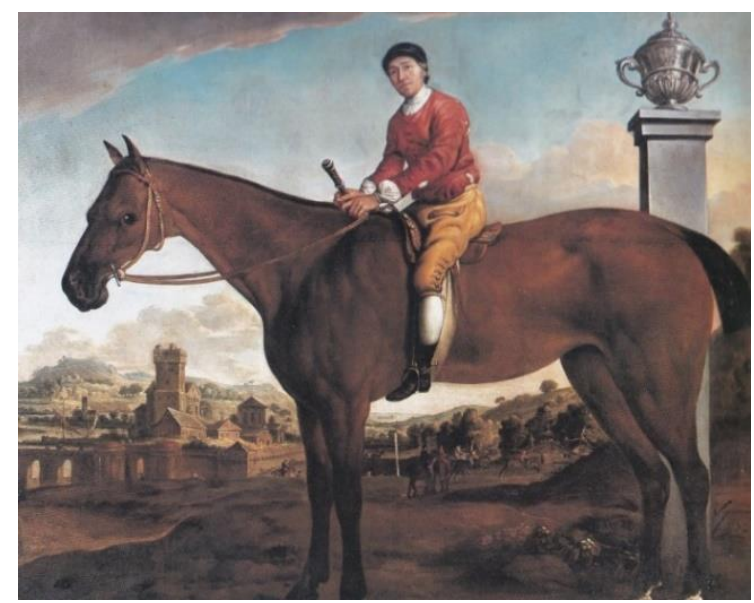

Fig. 1. Miss Neasham (Temple Newsam Hall, Leeds Art Galleries and Museums)

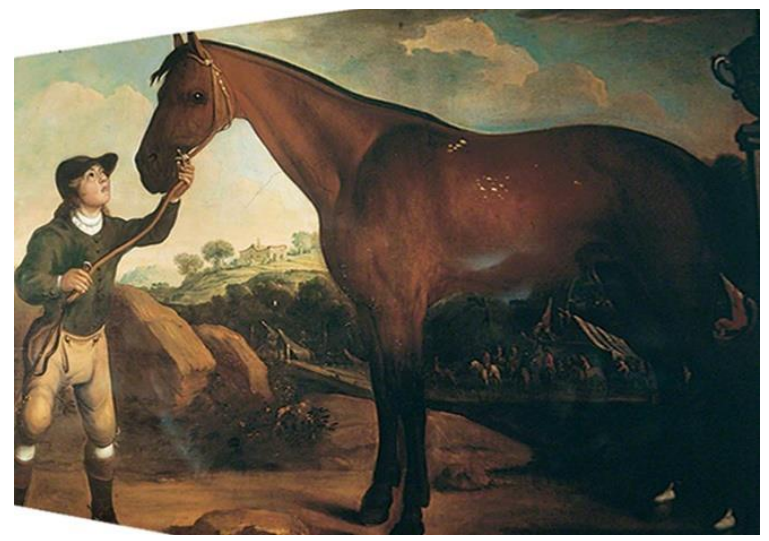

Fig. 2. Mother Neasham (Miss Neasham) (Leeds Art Galleries and Museums)

\section{B. Anne of Denmark's royal Frederiksborg}

My second example comes from the seventeenth century, and is a notable image within the Royal Collection (Figure 3). It depicts Anne of Denmark, wife of James VI/I, and was painted in 1617 by Paul van Somer. ${ }^{17}$ The date is significant; it was around this time that the first

\footnotetext{
${ }^{15}$ Nash, "The Thoroughbred as Cultural Metaphor", 250.

16 Ibidem; Alexander Mackay-Smith, Speed and the Thoroughbred, the Complete History (Lanham: The Derrydale Press, 2000), 5-6.

${ }^{17}$ Jerry Brotton, The Sale of the Late King's Goods: Charles I \& His Art Collection (London: Macmillan, 2006), 36.
} 
putative Arab horse enters the royal annals, which is only the second confirmed Arabian by name in English (or British) history, as will be discussed shortly. ${ }^{18}$ In the van Somer's portrait, the glorious green of Anne's hunting dress contrasts beautifully with the distinctive rich chestnut colouring of her flaxen-maned horse (Fig. 2). As Brotton describes the scene:

Anna strikes a relaxed, confident pose, dressed for the hunt, surrounded by the trappings of the landed English gentlewoman - Arab horses, Italian greyhounds (wearing monogrammed Queen Anna collars) and a fashionable black servant. In the background stands her favourite residence of Oatlands, rebuilt by Inigo Jones. ${ }^{19}$

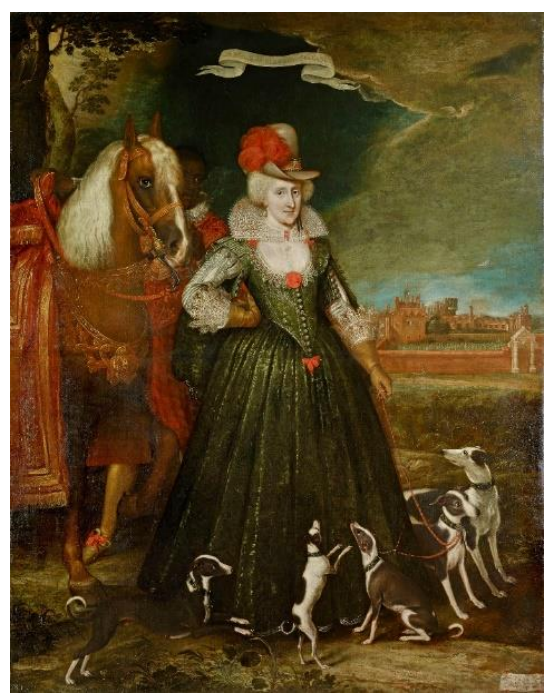

Fig. 3. Anne of Denmark (Royal Collection Trust /

(C) Her Majesty Queen Elizabeth II 2021)

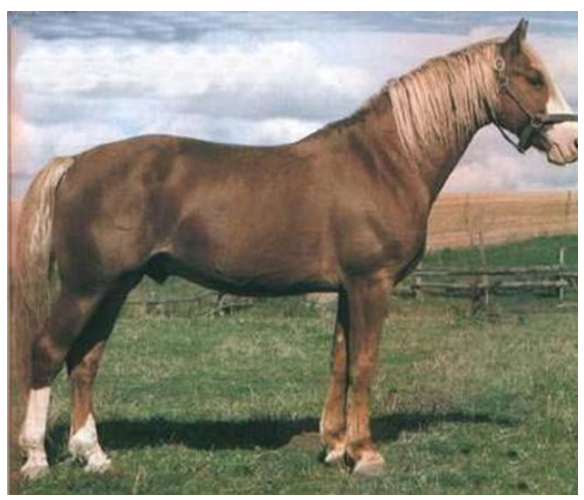

Fig. 4. Frederiksborg Horse

18 C. M. Prior, The Royal Studs of the Sixteenth and Seventeenth Centuries, (London: Horse and Hound Publications, 1935), 105. Various commentators, including Prior himself and the Duke of Newcastle, queried the provenance of this Arabia. (Ibidem).

${ }^{19}$ Jerry Brotton, The Sale of the Late King's Goods, 36. 
The issue is that the horse is not an Arab. To anyone knowledgeable about horse breeds, the horse is clearly an example of the famous Danish Frederiksborg breed, developed in the royal studs of that country in the early sixteenth century after the Reformation, using in part stock from monastic foundations, as well as Spanish stallions: "in the eighteenth century, the Frederiksborg was one of the most famous horse breeds in the world." 20 The Frederiksborg, Hendricks continues:

is a strong, attractive horse, always chestnut in color. Usually the mane and tail are a lighter, flaxen color. White markings on the face and/or legs are common. The head is well-proportioned, with a straight or sometimes convex profile, pointed, mobile ears, and large, expressive eyes... ${ }^{21}$

This description is an excellent match for the horse in the royal portrait. The implications of misidentification due to "Orientalist discourse" are clear. A horse that in fact represents a Danish cultural achievement and, in the case of the queen's horse, is probably symbolic of national and regal pride, is subverted by Orientalist beliefs regarding the enthusiasm of the elite for exotic equine imports. Although the Arab eventually influenced the Frederiksborg, this was much later. Further, although she cites no source, Amanda Murray notes that in 1605, among other equine gifts to the royal couple, Anne received "twelve mares from the King of Denmark." 22 This horse could therefore even be one of those mares, or one of their offspring.

\section{Shakespeare's Venus and Adonis}

The third example is a literary one. So deeply embedded is the myth of the Arabian that the horse of Adonis in Shakespeare's Venus and Adonis is identified without question as an "imported Arabian stallion" 23 by Miriam Jacobson in her recent book Barbarous Antiquity. This is despite the fact that Adonis's horse is consistently called a courser throughout the poem, a well-established term which refers to his speed and probably stamina, and that the mare he encounters is clearly described as a jennet. Nowhere is the stallion referenced as a breed of a specific country. However, Jacobson claims to recognise an Arabian from Shakespeare's description alone, ${ }^{24}$ and that courser is a term that was "typically applied to horses imported from North Africa and the Middle East." 25 Apart from this being yet another example of how vaguely geographical and descriptive terms are often applied, and why this matters, a courser is a description of what the horse does and how he does it, not where he is from. Further, Dent describes Adonis's horse as a hunter, correctly identifying him by "what he does," 26 and suggesting that he is "a text-book description of the perfect horse." ${ }^{27} \mathrm{He}$ is not supposed to be identified as a breed; he is an ideal. However, elsewhere Dent also comments that the "ideal" description in Venus and Adonis, like the ideal of other writers such as Nicholas Morgan, creates a "general impression...of the old stamp of the Andalusian horse," ${ }^{28}$

\footnotetext{
${ }^{20}$ Bonnie Hendricks, International Encyclopedia of Horse Breeds (Norman: University of Oklahoma Press, 1995), 188.

${ }^{21}$ Ibidem, 189.

22 Amanda Murray, All the King's Horses, (London: Robson Books, 2006), 42.

${ }^{23}$ Miriam Jacobson, Barbarous Antiquity: Reorienting the Past in the Poetry.

of Early Modern England (Pennsylvania: University of Pennsylvania Press, 2014); Kindle Edition. 23.

${ }^{24}$ Jacobson, Barbarous Antiquity, 124.

25 Ibidem, 117.

26 Anthony Dent, Horses in Shakespeare's England, (London: J.A. Allen, 1987), 25.

${ }^{27}$ Dent, Horses in Shakespeare's England, 26.

${ }^{28}$ Ibidem, 76.
} 
reinforcing it further by asserting that the "'fetlocks shag and long', 'broad breast', 'high crest', 'short ears', 'thick tail', 'broad buttock; were all hallmarks of the old Andalusian sort." 29

Mackay-Smith hints that the horse of Adonis might be a Hobby, since he notes that the Earl of Southampton was the dedicatee of the poem, and that his close friend the Earl of Rutland bred coursing horses from Hobby stock for hunting. ${ }^{30}$ Clearly a description of an ideal horse will conjure up whichever breed the period or individual considers to be the ideal; and at this time there is a far greater case to be made for it being a Spanish horse than an Arabian one.

However, descriptions of the ideal horse had been provided many centuries earlier by Isadore of Seville, subsequently developed by Albertus Magnus and given further chivalric qualities by Jordanus Rufus. ${ }^{31}$ Their descriptions also have much in common with the Elizabethan "ideal horse."

Other breeds might also claim the function of "courser." Synonymous with the concept of a courser is speed. Barbs had been imported into Italy for racing since at least the fifteenth century, particularly by the Gonzagas of Mantua for the Palio races. Hobbies were sent as gifts by Henry VIII in his attempt to obtain some of the emerging Gonzagan breed, and "Scottish Runners," identified by Tonni as Galloways, were cited as the fastest animals available to Henry. ${ }^{32}$ The Barbs that the Gonzagas acquired, unsurprisingly, came directly from north Africa as this was the closest place to acquire these indubitably fast horses, which are now acknowledged to be a distinctive north African phenotype, distnct from the Turk(oman) and Arab(ian) breeds. The Gonzagas were able to acquire examples of Turk and Barb horses, and even horses from India, but Arab(ian)s are never mentioned in the archives in the foundation period of the Gonzagan razze.

$V$ enus and Adonis was published in 1593, the same year in which Arab horses were first indisputably referenced by name in Britain, and Jacobson's work refers to this new development in publishing. It was the prolific writer Gervase Markham who provided the first plausible reference, in his work $A$ Discourse of Horsmanshippe in which he wrote of "the true Stallion, who for hys brave trotte, and pure vertue of valure in the Fielde, is a staine to all other Horses... whose wonderfull speede both in short and long courses, may make our English Prickers, hold their best runners but ?Bastardes?, who by nature hath all things perfect, nothing defective: him I hold a fitte Stallion to breede on, and a fitte beast for hys Maister to hazard his life on, and thys is onely the Courser of Arabia." 33

Markham further explained that he termed the Arabian a "Courser" because he had come across an old parchment written by a cleric in which it was stated that at when Hector and Achilles joined in combat, "Achilles rode on an Arabian Courser." 34 Taking inspiration from

\footnotetext{
29 Ibidem.

30 Mackey-Smith, Speed and the Thoroughbred, 34.

31 Eliaabeth Leet, "On Equine Language: Jordanus Rufus and Thirteenth-Century Communicative Horsemanship" in Animal Languages in the Middle Ages, ed. Alison Langdon (Kentucky: Palgrave Macmillan, 2018), 59-73. For the cultural and practical legacy of Jordanus Rufus, see also Jennifer Jobst, "Practical Advice on Equine Care from Jordanus Rufus, c. 1250 CE" in The Materiality of the Horse, eds. Miriam A. Bibby and Brian G. Scott (Budapest: Trivent Publishing, 2020), 35-69.

177 - 178. See also Jürg Gassmann, "Morality Tales and Misadventure: Horses in Medieval Ecclesiastical Writings" in Saints and Sinners on Horseback, ed. Miriam A. Bibby, forthcoming from Trivent Publishing. 32 Andrea Tonni, "The Renaissance Studs of the Gonzagas of Mantua," 274-275.

33 Gervase Markham, Discourse of Horsemanship (London: Richard Smith, 1593), 6-7.

34 This is somewhat suggestive of Andrew of Wyntoun's "Cumly Sted off Arabie" in reference to the equus Arabicus of Alexander II of Scotland. See Miriam A. Bibby, “Alexander's Arabian: Noble Steed or Fantastic Beast?" in The Materiality of the Horse, 185.
} 
this heroic association, Markham's description is an encomium for a horse, both physically and in terms of his individualistic character:

Thys Horse of Arabia, is of a reasonable stature, neyther too hie nor too lowe, but upright and cleane fashiond, hys head is small, leane and slender, hys nostrell (if he be angred) wonderfull wide, hys eyes like fire, readie to leape out of hys heade, hys eares sharpe, small, and some-what long, hys chavle thinne and wide, his thropell large, hys necke long, hys crest high, thinne and firm, his back short, hys chyne a handfull broade and more, hys buttocke long, upright and cleane, the sterne of hys tayle, welnie so small as a mans finger, but in strength beyond any other Horse, the hayre thereon so thinne as is possible: hys legges are small and cleane, having no hayre on his fetlocke, his body slender and rounde: in breefe, his cote in generall is so fine, that it is not possible almost in any parte of him but his mane and tayle, to catch holde to pull of one hayre. The collour of that Arabian which I haue séene, and which is even now under mine hands, is a most delicate bay, whom if you viewe in the Sunne, you will iudge him eyther like changeable Satine or cloth of Gold.

Thys Arabian is of nature milde and gentle to hys Ryder and Keeper, but to strangers most cruell: they will byte like Mastifes, if you offer to strike them, they will runne open mouthed at you like a dogge, and the more you strike, the more they will byte, they feare nothing, the night and day is with them all one: and as those Gentlemen report that have travailed in those Countreyes, they ordinarily lyve till fifty and thréescore yéeres. $[\ldots]^{35}$

Gervase Markham certainly knew how to sell a horse, particularly one whose USP was that it lived to be 110; and as apparently the only available Arabian sire in the country, Markham's Arabian would of course have been very desirable, according to Markham at least. While there is much debate around whether Arab horses were imported in pre-modern times, there is, as Dent commented, no actual evidence for it, simply hearsay: "I do not share the conviction of some writers that the Crusades 'must have' resulted in a large influx of Arab horses into 'Frankish' lands. There is but scanty written evidence for this, there is no proof, even, that the two 'most noble Arab horses' presented to Richard Coeur-de-Lion by Saladin ever reached the base on Cyprus, let alone England. Nor is it probable that many such imports took place." ${ }^{36}$ Further, As Nicholas Russell comments, "[Markham's] youthful enthusiasm soon wore off. In his book of 1607, Arab horses were not even mentioned." 37 Arguably, if Arabians were so ubiquitous prior to Markham's writing, why does he feel it necessary to emphasise to the reader the fact that he had actually seen the Arabian and indeed which even then was "under mine hands"?

Arguably, similarities could be found between Markham's description and that of Shakespeare in Venus and Adonis. However, Markham's eulogy is not original. Some of the defining elements of Isidore of Seville and Jordanus Rufus, cited earlier, would appear to be visible in Markham's description. Isidore of Seville had written in the seventh century CE that the ancients valued a horse with a "small, lean," head, sometimes described as "dry." 38 The ears should be short, pricked and expressive, the eye large and the "nostrils flaring." 39

\footnotetext{
35 Gervase Markham, Discourse of Horsemanship, 7.

36 Anthony Dent, The Horse through Fifty Centuries of Civilization, (London: Phaidon, 1974), 185.

${ }^{37}$ Nicholas Russell, Like engend'ring like: Heredity and animal breeding in early modern England (Cambridge: Cambridge University Press, 1986) 60.

38 Leet, "On Equine Language," 177.

39 Ibidem.
} 
Arguably, Markham takes an ideal historic template for a horse (other than the admittedly unusual "mastiff-like" qualities attributed to Arabians) and imposes it on his own "Arabian," rather than the other way round.

Of course, it is not impossible, or even unlikely, that Shakespeare was aware of Markham's work, though there is no proof that this influenced his own description of the courser. The postscript to Markham's 1593 encomium, however, is extraordinary. The fulsome description of the Arabian simply disappears from his later books, as Russell noted. Markham's subsequent publications (and he was an extremely prolific writer, not only on equestrian matters) make only passing references to Arabian horses, and other emerging breeds and types also take accolades, depending on which work and which edition it is. Since his works ran to many editions, some of them apparently using the same settings, we can be sure even from later editions that the original text of each particular edition has been little amended, if at all. Obviously in the early days of print, publishers and printers had to make judicious decisions about which type cases they stored, and Markham clearly sold well, so it was worth retaining the original settings. In fact, he was accused of flooding the market with all too similar texts, and asked to stop.

Markham's work thus provides the first "proof" of an Arab on the island of Britain, just as the work of Leo Africanus, first published in the 1550s, provided the first written identification of Arab horses in a European text. This will now be examined. Al-Hassan Ibn Mohammed Al-Wezaz, Al-Fasi (c. 1485 - c. 1554 CE) better known as Giovanni Leone, or Leo Africanus, achieved fame for his Description of Africa. Al-Fasi's first European translation was published as part of a collection of travel works by Giovanni Battista Ramusio, in the name of the latter. ${ }^{40}$

In a clear desire to re-educate his readership, about their use of the term "barbero," AlFasi wrote of horses within the Islamic world:

Cavallo Barbero, Questi cavalli sono detti nell'Italia, \& parimente in tutta l'Europa Barberi : percioche vengono di Barberia \& sono d'una specie, cheli genera in quei paesi. ma quelli, che han no li fatta oppenione, s'ingannano percioche i cavalli comuni di Barberia, sono, come glialtri, ma questi cosi agili \& correnti vengono chiamati nella lingua Arabica, cosi in Soria, in Egitto, in Arabia diserta \& felice, \& in Asia, cavalli Arabi \& tengono gli histori ci, che questa forte fosse di cavalli salvatichi, che andavano errando per li diserti di Arabia \& che da Ishmael in qua gli Arabi gli incominciassero à domesticare: in tanto , che crebbero in quantita, \& n'empieronol'Africa. ${ }^{41}$

However, as with Gervase Markham's publication adopting the term “Arabian horse," John Pory's 1600 translation of the above passage from Al-Fasi's work, while a decent version in English of the original, incorporated that subtle but damaging amendment from "Arab" to "Arabian," which would have long-lasting effects on the discourse:

Of the horse of Barbarie, His name is given unto the Barbarie horses throughout Italy and all Europe because they come foorth of Barbarie, and are a kinde of horses that are bred in those regions but they which so thinke are deceived: for the horses of Barbarie differ not in any respect from other horses: but horses of the same swiftnes \& agilitie are in the Arabian tongue

\footnotetext{
40 Giovanni Battista Ramusio, Delle navigationi et viaggi raccolto da m. gio. batt. ramvsio, \& con molti vaghi discorsi , da lui in molti luoghi dichiarato, \& illustrato. Nel quale si contengono la Descrittionoe dell'Africa, e del paese del Prete Ianni (Venice: 1558, Stamperia de Guinta, 1558).

41 Ibidem, 59.
} 
called throughout all Egypt, Syria, Asia, Arabia Felix, and Deserta, by the name of Arabian horses: and the Historiographers affirme, that this kinde of wilde horses ranging up and downe the Arabian deserts, and being broken and managed by the Arabians ever since the time of Ishmael, have exceedingly multiplied and increased, that they have replenished the most part of Africa. ${ }^{42}$

From this it is clear that Al-Fasi, understandably, identifies horses (notably swift and agile ones) belonging to Arab people, wherever they are found geographically, as Arab horses cavalli arabi - and not the horses of barbarians, or barbarous horses as the Europeans will insist on calling them! He also refers to the Abrahamic religious myth about Ishmael being the first tamer of horses in the desert. However, Pory uses "Arabian," to describe the horse, just as he will go on in the same passage to identify "Arabian" people and the "Arabian tongue" which last is a literal translation of Al-Fasi, although the former is not. ${ }^{43}$ Thus the horse is no longer an "Arab" horse, but an Arabian one, and arguably, the early myth of it emerging in the deserts of the Arabian peninsula is taken up by European writers, possibly Markham or possibly another as yet unidentified commentator who used "Arabian" rather than "Arab" to describe the horses which Al-Fasi (or his translator into Italian) unequivocally called "cavalli arabi," Arab horses.

Identifying the courser of Adonis as an import is essential for Jacobson's argument, since it is this, along with the purple flower (imported Turkish bulb) that allows her to "show [how] the imagery of horses and bulbs in the poem capitalizes on itself by linking Shakespeare's poetic remediation of Ovid with the imagery of valuable and fungible Levantine imports." 44 Since Turks (Turkoman) horses were known to be imported, if rarely, logically it would make far more sense to ally the horse and the bulb as both being Turkish imports to make the point. Jacobson also suggests that Heinrich Bünting's famous 1581 map illustrating Europe, Asia, and Africa as a winged horse is a visual expression of the reality of the value of "Oriental" horse imports, as it depicts Asia in the form of "Pegasus [as] an Arabian steed." 45 The title of the map does not refer to "Arabian steeds" but to "Asia, second part, in the form of Pegasus." The territory covered in the form of the horse includes everything from Scythia to "India Meridionalis." Further, Bünting created several other "fantasy" maps of the world, using human and animal forms, thus possibly establishing himself as creator of an amusing and entertaining genre that would be popular until the twentieth century; and there is no need to assume it was any particular "breed" at this time of early discourse relating to breeds and landraces.

Apart from Markham's generalised description, the earliest Arabian to appear in Britain with some documentary evidence was that sold to James VI/I by one "John Markham" in 1616, apparently under the influence of George Villiers, the King's lover, and Master of the Horse. The horse was subsequently known as "the Markham Arabian." James VI/I paid the sum of $f, 165$ in total, $f 150$ for the horse itself, and $f, 15$ for the man who brought it. Villiers, the Duke of Buckingham, is a key figure both in the development of the Royal Studs and racing in the north of England. Prior comments "judging from the price, [the Arabian horse] could not have been brought here from Arabia, as the actual freight would have been nearly as much...He may have been a son of the Arabian that Gervase Markham described." 46 The

\footnotetext{
42 John Pory, A Geographical History of Africa, written in Arabic and Italian by John Leo, a Moor born in Granada and brought up in Barbarie (London: Georg Bishop, 1600), 339-340.

${ }^{43}$ Ibidem.

${ }^{44}$ Jacobson, Barbarous Antiquity, 119.

${ }^{45}$ Ibidem, 120.

${ }^{46}$ Prior, 105.
} 
Markham Arabian may have had progeny, but the main focus in the royal studs was still on Barbs, Spanish and Neapolitan horses, as well as home-bred animals that were likely crosses of imports and home-raised British and Irish breeds such as Hobbies and Galloways, and these remained the focus for much of the following century. ${ }^{47}$

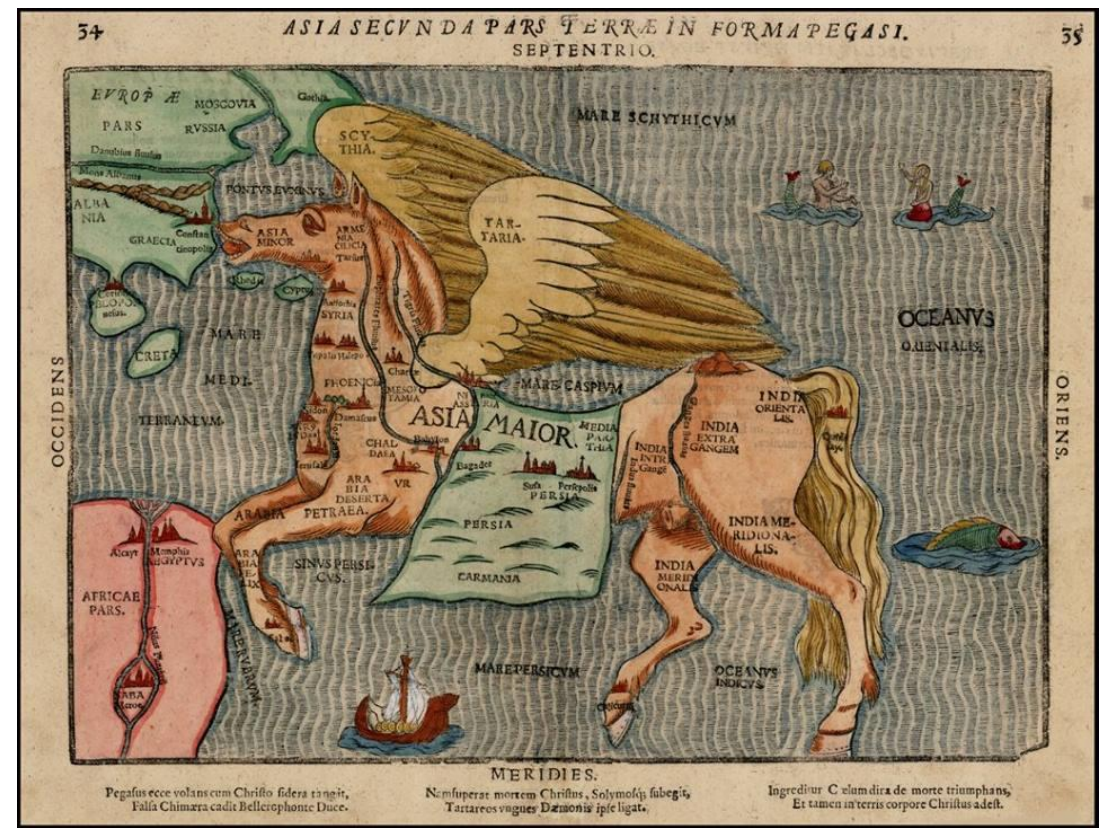

Fig. 5. Map of Asia in the form of Pegasus (Heinrich Bünting's map)

Further, that eminent equestrian William Cavendish remarked that he only ever saw one Arabian, presumably the Markham Arabian, and that this horse was a failure at racing. If one so knowledgeable about horses and horse breeds only ever saw one example, it would seem very unlikely that Arabian horses were as ubiquitous in previous centuries as some writers suggest. It is important to contextualise Markham's work within its time, a period in which various landraces and proto-breeds were being created, or at least recognised and promoted,

${ }^{47}$ On the majority of the imported "Oriental" stallions from the early period being designated Turks, and the difficulty in identifying the true "breed" of horse see amongst others C. M. Prior, The Royal Studs, 82- 83. That it was the fashion of the day early in the reign of James I to have foreign imports but that most were at that stage genets and Neapolitans, rather than Barbs (which still retained their popularity for some, notably William Cavendish), see Prior, The Royal Studs, 77: "An examination of the lists of the Royal studs which are now available, shew to what an extent they were recruited by the foreign-bred horses which had become the fashion of the day, every breeder wanting to possess a Neapolitan or a genet from Spain.” By 1620 Buckingham's marriage to Katherine Manners through which he acquired the famous Helmsley Estate in Yorkshire and its high quality horses, led "to some of Buckingham's mares from Marocco and Spain being established there and crossed with the good running breed already in the county." Prior, The Royal Studs, 71. That this breed was the Galloway, or a close relative of the same, and the part played by Yorkshire families (particularly their younger sons) from the late Elizabethan period onwards in matching imported stallions with native mares, see Anthony Dent, Cleveland Bay Horses (London: J. A. Allen, 1978) pp 38-39; also, Anthony Dent "Creation of a Breed," in Equi 22 (1984), 18-20. 
as I know from my own research into the Galloway nag, which emerges in the literary record almost simultaneously with the Arab(ian) horse. ${ }^{48}$ In this context, Markham's description of an Arabian horse suggests a short-lived novelty that he was promoting at that time.

\section{James Cossar Ewart, Wilfrid Blunt, and the Newstead "Arab"}

The fourth example, an archaeological one, is possibly the most problematic of all, due to the dating of the material involved, which has been used to promote various ideas regarding the antiquity and influence of Arab horses in Britain. Professor James Cossar Ewart was a key veterinary researcher in the late nineteenth and early twentieth centuries, with particular interest in the origins and antiquity of horse breeds, and an early investigator into genetics. He was instrumental in setting up the first animal breeding research establishments in Scotland. ${ }^{49}$ Ewart was the creator and major proponent of the "Celtic pony" theory. This was based on the idea that there was a distinctive Celtic type, distinguishable by certain features such as tail hair and lack of callosities (that is chestnuts on the leg). Ewart corresponded regularly with Wilfrid Blunt, traveller, and joint owner with Anne Blunt, of the Crabbet Arabian Stud. Wilfrid Blunt provided horses for Ewart's experiments. ${ }^{50}$

\section{A. James Cossar Ewart and the Newstead Report}

Ewart is best-known for his experimental work on telegony, which the Collins dictionary defines as: "the supposed influence of a previous sire on offspring borne by a female to other sires." In other words, that the female absorbs some of the qualities, or genetic material of the male, and that the first mating is the most potent, carrying on and influencing subsequent offspring. The link to concepts of male prepotency is clear, and the widespread interest in telegony in Cossar Ewart's circle of male correspondents and supporters of his research, a circle which included Blunt, Sir Alfred Pease, ${ }^{51}$ Professor Ridgway, ${ }^{52}$ and Bruce Lowe ${ }^{53}$ is revealing in itself.

There is no scientific basis to telegony and it is now wholly discredited. "Saturation," a concept developed by Bruce Lowe ${ }^{54}$ which James Cossar Ewart viewed as equivalent to telegony, ${ }^{55}$ had a specific genetic meaning for this circle of researchers. It indicated the "saturation" of a female by a prepotent male which, via the developing foetus, influenced subsequent matings either with that male, or with other stallions. This usage would have been

\footnotetext{
${ }^{48}$ Miriam Bibby, "How Northern was Pistol? The Galloway nag as self-identity and satire in an age of supranational horse trading", in Horse Breeds and Human Society: Purity, Identity and the Making of the Modern Horse, eds. Kristen Guest and Monica Mattfeld (Abingdon: Routledge 2020), 69-85.

${ }^{49}$ Clare Button, "James Cossar Ewart and the Origins of the Animal Breeding Research Department in Edinburgh, 1895-1920" in Journal of the History of Biology, Open Access 2017, DOI 10.1007/s10739-0179500-0.

${ }^{50}$ James Cossar Ewart, The Penycuike Experiments, (London: Adam and Charles Black, 1899). References to specific donations will be provided in this chapter where relevant to the argument.

51 Liberal MP for Darlington in north east England, and author of Horse-breeding for Farmers (London, Macmillan and Co, 1894).

52 Author of a controversial book on the origins of the Thoroughbred, and in conflict with the Blunts over his theories. William Ridgeway, The Origin and Influence of the Thoroughbred Horse, (Cambridge: Cambridge University Press, 1905).

53 Bruce Lowe, developer of the Bruce Lowe system of Thoroughbred breeding, published posthumously. Bruce Lowe, Breeding Racehorses by the Figure System, ed. William Allison (London, Horace Cox, 1895).

${ }^{54}$ Lowe, Breeding Racehorses by the Figure System, 197-221.

55 Ewart, The Penycuike Experiments 62.
} 
clear to their peer group and also to the generation of researchers that preceded them, including Darwin and Galton.

That the views of this time held for both humans and horses, is evident in the following anecdote (many of the examples presented by both Ewart and Lowe cannot be seen as genuinely scientific conclusions, but rather anecdotal examples), which is here quoted in full and without alteration:

One sent me the following case in human beings: "A light reddish haired, blue-eyed man, married to a half-caste (a cross of white man and aboriginal) woman, has three girls. The first bears unmistakable evidence of the black blood, her hair and eyes dark brown. The second might be placed amongst a lot of Anglo-Saxon girls, and, unless attention was drawn to her, she would pass as of pure white origin. The third daughter, now about seven or eight years old, has light flaxen hair and blue eyes, and where her skin is not exposed to sun is remarkably white." This was the substance of my friend's communication. ${ }^{56}$

In other words, according to the belief in telegony, as the white father had successive children with his "half-caste" wife, the children became allegedly more and more white, which was due, according to the theory, to the saturation of the woman by the white male via successive pregnancies which influenced, indeed came to dominate, her own genetic makeup via transfer from the foetus. Further examples are given in the book. Those who still use the term "prepotency" today should understand the implications of its use.

Cossar Ewart was sceptical about the theory of telegony, but nonetheless committed deeply to investigating it. For his own research he mated a zebra sire with a variety of mares, including individuals from the Highland, Icelandic, Shetland, Clydesdale, Irish (though not further specified) and Arab breeds, recording his results in academic journals and his book The Penycuik Experiments. The offspring were known as "Tartan Cuddies" by the locals in and around Penycuik. The ostensible motive for the zebra hybrids was to produce an equid that could survive in regions where tsetse flies or other serious issues made the use of horses problematic, and where rinderpest had decimated oxen; they were mainly proposed for use in Africa and India but this reason does not emerge until page 50 of The Penycuik Experiments. In other words, it was an imperial project aimed at producing a hardy type of mule. However, Ewart seems to have become immersed in the experiments, and the telegony debate, for its own sake.

Ewart was also the expert advisor and investigator into the equid remains from the Roman archaeological excavation at Newstead in Scotland excavated by James Curle, and Ewart's influence, and indirectly that of Wilfrid Blunt, on the report is clear. This site is important for the wealth of artefactual and skeletal material it produced. The terms "Arab" or "Arabs" appear nineteen times in the text in reference to horses. In comparison, the only reference to a modern Scottish breed, the Highland, is in a footnote, in which the head motif that often turns up in discourse relating to Arab horses appears once again: "Frequently in crosses between Arab and Highland ponies the head is decidedly longer than in either of the parents, probably owing to reversion to a large-headed ancestor". ${ }^{57}$ (The issue of large, coarse heads in comparison with allegedly "refined" Arab ones is a topic which I will develop further elsewhere.) The equid skulls are grouped into four types, corresponding to the taxonomic categories of the time, categories to which Ewart himself had contributed: the steppe (Equus

\footnotetext{
56 Lowe, Breeding Racehorses by the Figure System, 199.

${ }^{57}$ James Cossar Ewart, "Equidae" in James Curle, A Roman Frontier Post and its People (Glasgow: Society of Antiquaries of Scotland, 1911), 371.
} 
przewalskii); the Solutréan (Equus robustus), also known as the forest horse; the 'Siwalik,' which Ewar suggested was a descendant of a three-toed horse of the Himalayas; and the plateau horse, or Equus agilis, Ewart's own taxonomic creation, which "includes a northern ('Celtic') and a southern ('Libyan') variety," 58 and which he claimed he was able to recognise from Pleistocene times onward:

Teeth and limb bones from French and English Pleistocene deposits point to the existence of a fine-headed race from 12 to 13 hands high, with limbs slender as in the desert Arab and molars characterised by short internal pillars. Some of the drawings in the Combarelles cave apparently represent this slender-limbed 'plateau' race which I have named Equus agilis. ${ }^{59}$

Somewhat fortuitously,

Newstead has afforded no evidence of the existence in Scotland in olden times of a horse of the 'Steppe' or Przewalsky type, but it has yielded skulls which might very well have belonged to almost pure members of the 'plateau,' 'forest,' and 'Siwalik' types. ${ }^{60}$

"Two of the skulls from Newstead", commented Ewart elsewhere in the report:

...probably belonged to unimproved British native breeds, one of which certainly did not exceed 44 inches in height, while the other measured between 11 and 12 hands at the withers. The smaller one evidently belonged to a broadbrowed 'forest' pony, built on the lines of the strong thick-set modern Shetland ponies; the other is best represented to-day by small slender-limbed Exmoor ponies, and by ponies of the 'Celtic' type occasionally met with in the North of Iceland. ${ }^{61}$

A key feature of the contemporary debate relating to Arabians being that they improved other breeds, the statement regarding the "unimproved British native breeds" is noteworthy. With all bases apart from prewewalskii therefore well covered in the equid skulls discovered at Newstead, he was able to turn to those that would appear to be of greatest interest to him: the Equus agilis examples, which are compared to the skulls of Arab horses, or rather one "Arab" horse, in order to "creatively" demonstrate a relationship of the Newstead horses to Arabians, as I will show. Two images of very visually diverse skulls were used to indicate the difference between the "coarse-limbed" pony of the forest, or Solutrean type, versus the:

...slender-limbed horse of the 'plateau' type, about 12.2 hands high, from the Roman fort at Newstead. Length from occipital crest to alveolar point (i.e. point between central incisors, $494 \mathrm{~mm}$; length from line connecting supraorbital foramina to alveolar point, $338 \mathrm{~mm}$; frontal (greatest) width, $185 \mathrm{~mm}$. Owing to the face being long and narrow, the frontal index $(185 \times 100 \div 338)$ is 54 , as in high-caste Arabs. ${ }^{62}$

Photographs of limb bones are also shared to indicate the difference between the "forest pony and the "plateau" type. The "facial index" reference relates to the common value judgement practice of both anthropologists and archaeologists at that time: drawing conclusions about ethnicity from the ratios of measurements of the skulls of humans, a

\footnotetext{
58 Ibidem, 363

59 Ibidem.

${ }^{60}$ Ibidem.

61 Ibidem, 364.

62 Ibidem inter pages 364-365.
} 
technique which was also applied to animal species. The concept of Swedish anatomy professor Anders Retzius (1796-1860), the cranial index was based on the following formula: maximum width of the head multiplied by 100 divided by maximum length of the head. The cranial index is still used in anthropology today, although many studies have shown that it is not a racially fixed characteristic, theories of racial difference having been shown to be false constructions; the facial index is subject to considerable plasticity and children frequently have greatly different characteristics from their parents. ${ }^{63}$ The human remains from Newstead were investigated using a similar approach to the animal species and described using similar terminology. ${ }^{64}$ However, the interesting aspect of the human remains section of the Newstead publication is that it offered no attempt at racial identification, unlike the attempt to identify breeds or archetypes in the Equidae section. It was certainly not uncommon for archaeological investigators to attempt to categorise human remains racially. In fact, it might be argued that the chapter on human remains at Newstead treated its subjects rather more sympathetically, and in less of a categorical fashion, than the horses:

There is great variety in the cranial characters of the several specimens, and no ethnological data emerge from an examination of the collection. It is not possible to say whether the individuals were strangers or natives, nor to identify the races to which they belonged. It is curious that such a large proportion of the persons buried in this casual way were still in early life.

The case of the dwarfish girl excites more interest. The circumstances in which the skeleton was found are remarkable. The body had been thrown into a refuse pit, and there lay under the carcases of as many as nine horses. What part did this tiny person play in the fort, and why did her remains receive such scant respect? ${ }^{65}$

The section by Ewart relating to equidae in Curle's Newstead report is some thirteen pages long, several of which are devoted wholly or partly to photographs or illustrations. In it, the Arab is frequently cited in flattering (and familiar) terms:

From the size of the cranium, the dimensions of the narrow, tapering and only slightly deflected face, and from the slenderness of the limbs, it is evident that this pony was built on the lines of the smaller kinds of modern Arabs. Further, the relatively large cranium indicates that it was probably as intelligent and docile as Arabs are. ${ }^{66}$

The other remains, on the other hand, are not flattered; and despite having said there were no skulls indicative of the "steppe" (Przewalski) type at Newstead, Ewart nonetheless writes:

The majority of the remaining skulls belonged to coarse-headed animals, which may very well have been a blend of the 'Siwalik' and 'steppe' types. ${ }^{67}$

The evidence in the report suggests that Ewart was keen to identify some of the equid remains as fitting into specific categories, or being crosses of these types. It also appears to

\footnotetext{
${ }^{63}$ This methodology was already being critiqued just after the publication of Curle's excavation report. See F. Boas \& H. M. Boas, "The head-forms of the Italians as influenced by heredity and environment" in American Anthropology. 15, (1913) 163-188. [Google Scholar].

${ }^{64}$ Curle, Nenstead Report, 380-384.

${ }^{65}$ Ibidem, 384

${ }^{66} \mathrm{Ibidem} 365$.

${ }^{67}$ Ibidem 370.
} 
have been particularly important that some were of a "plateau", or Libyan type that potentially could include both "Celtic" and "Arab" sub-strains that were related yet had developed independently. Value judgements regarding intelligence and "coarseness" emerge, which are related to the "improvement" debate.

\section{B. Jerboa's Story}

The Arab horse skull used for comparison with the assumed Arab-like "plateau" horse from Newstead was that of Jerboa, a horse belonging to the Blunts. In the report, Ewart stated that the skull was in the British Museum. ${ }^{68}$ Evidence from elsewhere shows that Jerboa was purchased at Deyr, on the Euphrates, to the south east of Aleppo, from a horse sale in 1877. ${ }^{69}$ She was therefore purchased nowhere near Najd, which the Blunts believed at that time was the home of the "pure," or Asil, Arabian, and she was also clearly purchased in a hurry during a time of crisis:

There was even a chance [Hussein Pasha, the Turkish Governor] hinted, that Deyr itself might be attacked. Dismayed at the alternative of being sent back to Aleppo empty-handed, the Blunts accepted the Governor's proposition that they attach themselves to a caravan shortly to leave for Baghdad, even though it took them well away from their tribes [ie the tribes they wanted to contact, the Anazeh]. The only consolation was the fact that Deyr served as a considerable horse market for the surrounding tribes and during the short time that they were there, they managed to buy Jerboa, Francolin, and, for Lady Anne to ride, a Saadeh Tokan mare they named Tamarisk. ${ }^{70}$

Jerboa was among the first group of horses sent back to England. ${ }^{71}$ She is noted as having a filly in $1881,{ }^{72}$ and later that year (October) as being driven by Lady Anne Blunt. ${ }^{73}$ She was used by Anne to draw comparisons in her journals with horses at home and abroad, Jerboa always proving superior to those to which she was compared, and she is referenced as being one of the horses shown to visitors to Crabbet Park Stud, among many other brood mares. ${ }^{74}$ Finally, a foal from Jerboa by the Blunts' premier stallion Pharaoh was bought by a neighbour of the Blunts, Miss Dillon, who also bred Arab horses though she came in for much criticism from both Blunts. Anne Blunt later regretted the sale of this filly foal, Jerud. ${ }^{75}$ However, and most interestingly, she comments "But now, if Miss Dillon wished for an exchange, Jerud is spoiled for us because she has had foals by Emir."76 In other words, the principle of telegony meant that Jerud was forever spoiled as a brood mare due to her "infection" by Miss Dillon's

\footnotetext{
68 Ibidem, 368.

${ }^{69}$ Rosemary Archer, Lady Anne Blunt: Journals and Correspondence 1878 - 1917, eds. Rosemary Archer and James Fleming (Northleach: Alexander Heriot, 1986), 16.

${ }^{70}$ Ibidem, 16. This story only appears in Archer's edited version of Anne Blunt's journals, and does not appear in The Crabbet Stud, its History and Influence by Rosemary Archer, Colin Pearson, and Cecil Covey. In that book, Jerboa is simply listed among the first horses bought and brought to England, several of whom had their names changed on arrival, though Jerboa it seems did not. Rosemary Archer, Colin Pearson and Cecil Covey, The Crabbet Arabian Stud, Its History and influence (Northleach: Alexander Heriot \& Co, 2002), 39.

71 Ibidem, 39.

72 Ibidem, 125.

73 Ibidem, 143.

74 Ibidem, 144, 164, 244.

75 Ibidem, 410, 412

76 Ibidem, 412.
} 
"inferior" stallion El Emir, purchased in Algiers, and despised by the Blunts for his lack of beauty and provenance. ${ }^{77}$

The first Arab horses belonging to the Blunts to arrive in Britain, including presumably Jerboa, were entered into the G.S.B. (the General Stud Book, in which all Thoroughbreds must be registered) under the influence of Wilfrid Blunt. Tattersall's, the compilers of the G.S.B. were present at the first and subsequent horse sales at Crabbet, after which Mr. Tattersall was reported locally as saying:

The country was greatly indebted to Mr. Blunt for his endeavour to confer a national good by the introduction of originally pure stock, from which all our Thoroughbreds had been obtained, and he had no doubt that with the assistance of the soil and climate of England the Arab steed would develop and become a larger animal ... All the animals were entered in the Stud Book and could be traced to ensure their purity [...] Blood was everything in breeding, and blood was there. ${ }^{78}$

I have not as yet viewed the G.S.B. records. However, both Jerboa and the circumstances of her acquisition are recorded in Lady Anne's own stud book of 1897, in which Jerboa is described as:

A Managhyeh Hedrujieh, ${ }^{79}$ foaled in 1874.14 hands $2 \frac{1}{2}$ inches, a light bay mare with three white feet (two fore and near hind) and star. Head shewing breeding though not handsome, eye large and flashing and shewing some temper, ears remarkably good, mane very fine, shoulder well sloped though hardly any wither up to the age of 7 , very strong back, good sound wiry legs but not large bone, tail well carried, splendid action trotting and fast, and good mover galloping, the stride being smooth and even as a machine, good leader in a team, though inclined to kick if annoyed.

Jerboa's dam a bay Managhyeh Hedrujieh, long and low and very worn, old and thin when seen at Deyr in 1878. Her sire a Managhy Ibn Sbeyel of the Gomussa. Extract from journal Deyr Jan. 211878 'a bay filly was brought. Managhyeh, yet strange to say good looking and for her we are to treat'. Purchased at Deyr Jan. 24, 1878 from her breeder Othman al Abd of the Obeyd tribe. Imported 1878. Jerboa died in 1893.80

It has to be presumed that no documentation was provided at the point of sale, since none is cited. It should also be kept in mind that the Blunts, however elevated the language or captivating the story, were horse dealers buying from horse dealers. Much of the "evidence" is simply what they claim they were told, and what they told others who wished to buy their horses. Quite how, or why, Jerboa's skull should have arrived in the British Museum as Ewart states, is unclear, and I have been unable to find any record of it having been there. As Ewart describes it, "the skull of one of these slender-limbed 14 hands horses [from Newstead] is almost identical with the skull of an Arab mare (Jerboa, by Maidan out of Jerud) in the British Museum. That they closely agree is especially suggested by the frontal index." 81

\footnotetext{
77 Ibidem 409.

78 Archer, Crabbet Arabian Stud, 54-55.

79 Anne Blunt's version of Muniqui, one of the horse strains recognised by modern Arab horse breeders.

80 Archer et al, Crabbet Arabian Stud, 98.

81 Curle, The Newstead Report, 368.
} 
There are three concerns here. Firstly, the two mares mentioned, Jerboa and Jerud, were Crabbet Stud Arabians, although this is not acknowledged. Indeed, neither the Blunts nor their stud are referenced in Ewart's Newstead summary. The stallion Maidan was owned by Miss Dillon, and although Anne described him as "all right," 82 and "a fine horse" 83 in comparison to the Blunts' disparaging remarks about Miss Dillon's other stallion El Emir, Anne questions the provenance of Maidan, commenting, "but the certificate has disappeared - certificates always do, I think - and so there is no proof or record, not even a name of breed." 84 Secondly, the genealogy is incorrect. There was only one Jerboa and only one Jerud, as far as I can tell from the stud records; and Jerud was, as noted earlier, the daughter of Jerboa, and her sire was Pharaoh, acknowledged by the Blunts to be one of their best stallions. Under Jerboa's entry in the family summaries in Archer's book on the Crabbet Stud it is clearly stated: "Jerboa also had a daughter by Pharaoh called Jerud who, when mated with Miss Dillon's stallion Maidan, produced the colt Jamrood who appears in the pedigree of Nuri Sherif and in Hagar's line from Zem Zem." 85

In Ewart's report, the daughter becomes the mother, and the mother, the daughter; and another stallion belonging to a neighbour (and frequently despised rival) is claimed to be part of the breeding! Why the genealogy should have become so mixed-up in the report is not clear; it may simply be an error on Ewart's part, though as subsequent evidence shows, that is unlikely, as will be discussed later in this paper. The use of Jerboa as a reference matters, though since it is presented as major evidence for Ewart's argument regarding his "Libyan/Celtic" theory. He even goes so far as to call the example from Newstead an Arab, although he does use quote marks. Of the greatest significance is the conclusion he draws from this:

In the Arab mare Jerboa the face has a length of $368 \mathrm{~mm}$. and a width of 205 $\mathrm{mm}$., hence the frontal index is 55.7; in the Newstead 'Arab,' the length of the face is $372 \mathrm{~mm}$. and the width $201 \mathrm{~mm}$., which gives an index of 54. This implies that in the first century, in a 14 hands horse of the 'Libyan' type, the head was as fine as in modern Arabs. It may be added that the fine-limbed 14 hands Newstead horse of the Libyan type, though smaller, was built on the same lines as the thoroughbred 'Orlando,' but decidedly differed in make from 'Stockwell,' the grandson of the 'fiddle-headed' Echidna. The skulls and limbbones already referred to show that the garrison of the Newstead Fort had in their possession (1) broad-browed big-boned ponies of the 'forest' or robustus type from 11 to 12.2 hands; (2) slender-limbed ponies of the 'Celtic' variety, of the 'plateau' type from 11.2 to 12.2 hands, and 14 hands ponies of the 'Libyan' variety of the 'plateau' type built on the lines of the finer kinds of desert Arabs. ${ }^{86}$

This touches closely on the contemporary debate regarding the contribution of the Arab(ian) to the Thoroughbred racehorse, which is a theme I will develop elsewhere, and the alleged survival of "coarse" heads from the "native" stock, mainly Galloways and Hobbies, ${ }^{87}$ that Lady Wentworth, daughter of the Blunts, would later describe as:

\footnotetext{
82 Archer et al, Lady Anne Blunt: Journals and Correspondence, 410

83 Ibidem 12

84 Ibidem.

85 Archer et al, Crabbet Arabian Stud 243.

${ }^{86}$ Curle, The Newstead Report, 368.

${ }^{87}$ In fact, it was the genetically diverse "native" stock which provided the speed gene: Bower, et al, "The cosmopolitan maternal heritage of the Thoroughbred racehorse breed shows a significant contribution from British and Irish native mares," doi:10.1098/rsbl.2010.0800
} 
the ruck of our degenerate throw-outs at Tattersalls... the unwelcome heavy heads and pig eyes or goose rumps are reminders of undoubted blots on the escutcheon, of the foreign coach- and cart-horse alloy, seldom seen in the classic flyers which follow the better lines of ancestry...These coarse types are partial reversions to the cold-blooded, slow, primaeval stock, Equns Frigidus; and the classic type represents hot-blooded, slender, nimble and fine-headed racing blood, Equus Arabicus. Most of us realise this by instinct, for a 'fiddlehead' is not generally considered by the best authorities a signal proof of highclass superior breeding; in fact the adjective 'fiddle-headed' aptly describes our slowest types. ${ }^{88}$

Ewart's conclusion is therefore apparently drawn from the measurements of a single skull, that of a mare purchased by the Blunts at Deyr on the Euphrates (assuming it actually was Jerboa's skull that was used), whose ancestry is incorrectly described in Ewart's report, in comparison with that of a single skull from Newstead. The lasting effect was the reification of Ewart's "Libyan/Celtic/Arab" archetypal models and their acceptance into academic theory, which acceptance endures, to some extent, until this day. ${ }^{89}$

What is more, the Scots could now lay claim to the fact that they had horses of "Arab" type, at least from the days of the Romans onward, if not earlier! This presumed concession to local pride is also the third of the problematic issues of his interpretation; along with the Arab prototype/archetype/variety, Ewart creates a "Celtic" variety, which is essentially a descendant of the same plateau, or Libyan, strain, but makes no comment on when this strain may have arrived, in Roman or pre-Roman times. (Comparisons might be drawn with origin tales of Scota and Gaythelos as primordial ancestors to the Scots.) As noted previously, Ewart does also use some Icelandic horses as examples of his "Celtic" pony type, which has a certain logic to it, as a distinctively and undeniably northern breed; however, if the skull of the Newstead 'Arab' matches so well with that of Jerboa, how likely is it that the skull of a mare bought in the valley of the Euphrates in the nineteenth century CE would also match that of a putative Celtic/Icelandic horse of some 2000 years earlier, or even a modern Icelandic? If very likely, then any attempt to define breeds by head is pointless; if unlikely, then there is no reason that Ewart's proposed 'Arab' and 'Celtic' types, even if essentially descendants of the same Libyan strain, should match at all.

Footnotes to Ewart's text relate to the skeletons of the Thoroughbreds Orlando and Stockwell, both of which were museum exhibits, and therefore available for study. Allocating to Jerboa the status of a museum exhibit rather than a Crabbet brood mare effectively placed her at a remove from the Blunts. Also, giving her an ancestry beyond the fact that she was a purchased mare, incorrect as this ancestry was, did avoid the issue of her real origins and ownership.

Further, what is to be made of the fact that Lady Wentworth apparently upholds the incorrect genealogy regarding Jerboa provided by Ewart: "There was, however, [at Newstead] a fine-headed, slender-limbed race like desert Arabs... [with a] skull corresponding to that of

\footnotetext{
${ }^{88}$ Lady Wentworth, The Authentic Arabian Horse and his Descendants (London: George Allen and Unwin, 1957), 44

${ }^{89} \mathrm{~A}$ recent publication adopts a variation on this consisting of a "warmblood subspecies or now extinct Forest horse," the draft subspecies, "probably related to today's draft horses and even the Shetland pony" and the "oriental subspecies, a tall, slim, refined, and agile animal that arose in Western Asia (leading to the Akhal-Teke and Arabian)." Debbie Busby and Catrin Rutland, The Horse: a Natural History (London: Ivy Press, 2019), 162.
} 
the Arab Jerboa whose dam Jerud was bred at the Crabbet Stud"90? This, despite the fact that her stud manager Cecil Covey commented that "Her memory was astounding and I never knew her to be a loss on a pedigree, be it one of her horses or somebody else's." 91 The evidence of Newstead, and images on early coins indicates, according to Lady Wentworth, "The great admiration for the early British horse, which they [the Romans] praised as superior to anything they possessed, [and] suggests that the Arabian type... really existed in England." 92 In other words, the Arab type was there in pre-Roman times according to Lady Wentworth. This certainly contradicts some of her later statements on Arabian horses.

Further, Lady Wentworth must have known who Jerboa was, as she was one of the first mares brought to Crabbet, therefore an important part of the foundation story of the stud. It is hard to believe that she did not know the information provided in the Newstead report was incorrect.

There is one long shot, but I have not seen any evidence to support it. That is, that Miss Dillon bred Jerud to Maidan and subsequently named the offspring of that match Jerboa, after the foal's granddam. This is highly unlikely, for two reasons. The first is the total lack of evidence for that, although there are references to breeding Jerud to El Emir, as noted with distaste by Anne Blunt. The second is, quite simply, it would lead to confusion, and many studs avoid the practice of duplicating names for this reason.

\section{Jerud's Story}

Jerud, like her mother Jerboa, is in fact well documented. She was bought twice by Miss Dillon. She was first bought in March 1885 along with another Crabbet mare, Raschida, who had at first been named Wild Honey. Jerud was also known, somewhat romantically as "a poet's dream," and was considered to be an excellent mare. ${ }^{93}$ On September 29 $9^{\text {th }} 1890$, Anne Blunt and Judith visited Miss Dillon, then residing in Oxfordshire, at which point the comment about being spoilt was made, as well as it being a pity that they had ever sold Jerud to Miss Dillon. However: "The only satisfactory [foal] she has had seems to be the 2 year old by Maidan." [Jamrood] ${ }^{94}$

In 1895, Miss Dillon was selling stock at a sale and "the Blunts secured Jerud but little else was sold," so clearly she was sold back to the Blunts..$^{95}$ The next references to Jerud relate to a mare called Dinarzade, who was purchased by Miss Dillon. However, the mare having proved too difficult for her, as she had for other owners, she "in 1899 exchanged her [with the Blunts], by this time with El Lahr at foot, for Jerboa's daughter Jerud." This is confirmed in Anne Blunt's diaries for 22 $2^{\text {nd }}$ June 1899: “A letter from Miss Dillon wanting to give Dinarzade for Jerud, saying she would never have sold the latter, etc. Now Dinarzade would be worth more than Jerud, as Jerud's foals do not seem satisfactory, but one does not want to take advantage of Miss Dillon..." 96 By June $28^{\text {th }}$ the diary reads: "Webb is in communication with Miss Dillon in reply to her request to have Jerud in exchange for Dinarzade. He appears to have settled with her to that effect." 97 A footnote reads that Miss Dillon thus acquired Jerud again in 1899 in an exchange with the Blunts for Dinarzade. The

\footnotetext{
${ }^{90}$ Lady Wentworth, Thoroughbred Racing Stock (London: George Allen \& Unwin, 1938), 168.

91 Archer et al, The Crabbet Stud, 214.

92 Lady Wentworth, Thoroughbred Racing Stock, 170.

93 Archer et al, Lady Anne Blunt: Journals and Correspondence, 410.

94 Ibidem, 412.

95 Ibidem, 418

96 Ibidem, 272.

97 Ibidem, 273.
} 
mare, presumably Jerud, died in the winter of 1904/5. None of this information suggests any foal from Jerud that could possibly fit the bill.

Further, why would the skull of Jerboa allegedly have been in the British Museum, and why the best choice for comparison with the horses at Newstead? This question does not appear to have been asked in the report. This confusion between mother and daughter it seems to me is deliberate, not accidental; and in fact the British Museum reference is completely, and perhaps deliberately, misleading, as will shortly be shown.

Although Lady Wentworth upholds the incorrect genealogy, she contends with Ewart's taxonomy, however, particularly "the inference that the Northern stock was the common ancestor of the Arab and Tarpan, whereas the Arab is a root stock in itself and the Oriental Celtic type is derived from crossing the indigenous European pony stock with Arab blood." 98 "Professor Ewart," she continues, apparently with unconscious irony, "(like Professor Ridgway) suffered from a confusing propensity to plant his genealogical trees upside down." 99 There then follows in her work a discussion of whether the tail lock to keep out the wind, a feature that Ewart felt was indicative of the "Oriental Celtic"100 type, is confined to that type, or whether it is a feature of coat growth common to all horse breeds. This is then immediately followed by several pages of unrelated material on the theme of gipsies and their origin, of whom she opines: "In England they have obviously degenerated in blood and been mongrelised, till at the present day a 'pure' gipsy is probably almost non-existent, and there is little to distinguish the caravan dwellers from any wanderer who finds fortune-telling more profitable than hard work." 101 This type of diversion is, as scholars have noted, not untypical of Lady Wentworth's commentary; Richard Nash measuredly describes her writing as "colorful." 102

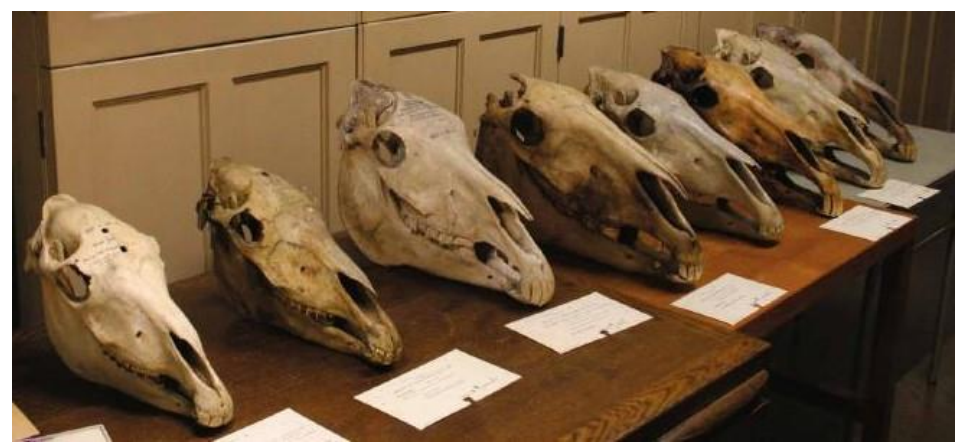

Fig. 6. Skulls donated to the Natural History Museum by Lady Wentworth of the Crabbet Stud. Jerboa is fourth from right without a card description in front. Photo by Jessie Preece, used with kind permission of Jessie Preece and the Natural History Museum, London.

The postscript to the Jerboa-Jerud story is an interesting one in itself. Jerboa's skull is not in the British Museum, but rather in the Natural History Museum in London, which makes

\footnotetext{
${ }^{98}$ Lady Wentworth, Thoroughbred Breeding Stock, 174.

99 Ibidem.

100 Ibidem.

101 Ibidem, 175.

102 Richard Nash, "Honest English Breed": the Thoroughbred as Cultural Metaphor" in The Culture of the Horse: Status, Discipline, and Identity in the Modern World, eds.Karen Raber and Treva J. Tucker (Basingstoke: Palgrave MacMillan 2005), 259.
} 
far more sense. Or is it in fact Jerboa's skull? An article by Jessie Preece in Arabian Horse News in June 2015 adds further to the mystery. ${ }^{103}$ Preece describes viewing a collection of skulls from Crabbet donated to the Natural History Museum by Lady Wentworth and provides a photograph of the skulls of the following individuals: " 5 month old filly (Skowronek $x$ Nasira), skull of a 9-month-old Arabian colt, skull of Skowronek, skull of Anglo, skull of Jerboa H 11, skull of Bint Nura, skull of Risala, skull of Dwarka."104 However, apparently, with regard to the supposed skull of Jerboa: "this name was crossed out and replaced with Hayat-en-Nufous (Jamrood x Harik)." 105 The mystery thus deepens; if this is not Jerboa's skull, where is her skull? How did this skull arrive in the Natural History Museum as part of a collection donated by Lady Wentworth, long after the publication of the Newstead report? Was Jerboa's skull ever in the British Museum at all?

These questions remain unanswered currently. However, one thing is clear. The deployment of the arguably manipulated, or at least controlled, evidence allowed Ewart to bring together his over-arching "missing link" equine theory that:

The slender-limbed 12-13 hands Newstead ponies are especially interesting, because they form a connecting link between modern ponies of the Celtic and Libyan types and the slender-limbed prehistoric races represented by teeth or limb-bones from the Pleistocene deposits of North Africa, Central France, and the South of England, and from Neolithic deposits. ${ }^{106}$

\section{Wilfrid Blunt, James Cossar Ewart and the Penycuik Experiments}

Despite lack of references to the Blunts or Crabbet Park in the Newstead report, there is no shortage of references to Wilfrid Blunt elsewhere in the work of James Cossar Ewart. On page lxvi - lxvii of The Penycuik Experiments, Ewart mentions correspondence in which Wilfrid Blunt had sent Ewart information relating to the coat colours of the twenty foals born at Crabbet in 1898 in an attempt to investigate the influence of the sire on coat colour. On page lxx Ewart reveals that: "Mr Wilfrid Blunt has recently been good enough to present me with a high-caste Arab foal, showing as distinct stripes in the region of the "knee" and hock as in Norwegian dun-coloured ponies". Ewart then comments "that stripes are less common in Arabs and their thoroughbred descendants is due, I believe, to Arabians disliking duns, which they say 'are only fit for Jews to ride'." 107 On page 115, he informs the reader that: "Mr Wilfrid Blunt has been good enough to send me some particulars of his 1897 crop of Arab foals," 108 noting the presence of stripes, and adding: "The desert Arabs seem to dislike dun-coloured horses, and, probably owing to the duns being weeded out, stripes are comparatively rare in high-caste desert-bred Arabians." 109

\footnotetext{
${ }^{103}$ Jessie Preece, "A visit to Crabbet Park and the Crabbet collection at the British Natural History Museum” in Versatile Arabian Horse Magazine, Australian Arabian Horse News, June 2015, 26 - 28. Viewable at: https://issuu.com/vinkpublishing/docs/ahn_june_15/30.

104 Ibidem, 28.

105 Ibidem 27.

106 Curle, Newstead Report, 366.

107 Ewart, The Penycuik Experiments, lxx.

108 Ibidem, 115.

109 Ibidem, 115. The entire "stripes" experiment was based on Darwinian principles of reversion, which argued that a primordial ancestor of the horse had been striped, and that stripes in modern horses were an indication of reversion to that type. Darwin wrote: "I am aware that Colonel Hamilton Smith, who has written on this subject, believes that the several breeds of the horse have descended from several aboriginal species - one of which, the dun, was striped; and that the above-described appearances are
} 
With regard to his telegony experiments, Ewart notes that "Mr Wilfrid S. Blunt, on hearing of the experiments through the late Professor Goodhart" was "generous enough to send me an Arab mare 'Bernabit"' (who was referenced among the brood mares to be viewed by visitors to the Crabbet Park Stud in October 1892110). Ewart also writes that "The Arab mare, Bernabit, when set free in the field, carries her head high in the air in a most suggestive way when she gallops about. The zebra horse, on the other hand, carries his head low, and twists his neck as if engaged in single combat, ready to seize the limbs of an adversary." 111

A comment is passed on one of his "tartan cuddies" that "his action when trotting is even more perfect than that of his stable companion the high-class Arab horse Benazrek." 112 A stallion named "Ben Azrek" is listed among the horses related to the Crabbet Arabian Stud, but little appears about him in Archer's book. Ben Azrek is referenced therein, unsurprisingly, as a son of the stallion Azrek, ${ }^{113}$ out of the mare Shemse. ${ }^{114} \mathrm{He}$ is also referenced as being a less important line of Pharaoh ${ }^{115}$ and being a grandson of the foundation mare Sherifa. ${ }^{116}$ This is undoubtedly the same Benazrek as referenced by Ewart, who remarks that "In all the offspring of my Arab Benazrek there is a characteristic blaze. ${ }^{117}$ This might be to some sufficient proof of prepotency. But a blaze may be of the nature of a 'sport,' and if this is not the right explanation his breeding has to be taken into consideration. He is not only wellbred, he is highly bred; whereas the dams of his offspring, with the possible exception of Mulatto, ${ }^{118}$ are of mixed origin, or as we say, cross-bred." 119

all due to ancient crosses with the dun stock. But I am not at all satisfied with this theory, and should be loth to apply it to breeds so distinct as the heavy Belgian cart-horse, Welch ponies, cobs, the lanky Kattywar race, etc., inhabiting the most distant parts of the world." (Charles Darwin, Complete Works of Charles Darwin English Naturalist and Geologist, 23 Complete Works (On the Origin of Species, Voyage of the Beagle, Autobiography, Life and Letters, Volcanic Islands) (Annotated) (Kindle Locations 81760-81763). It would appear that for some considerable time, many of the learned gentlemen in Darwin's circle were "spotting stripes."

110 Archer et al, Lady Anne Blunt: Journals and Correspondence, 244.

${ }^{111}$ Ewart, The Penycuik Experiments, 10. There is not much to be inferred from this comment. Most horses, whatever their breed, hold their heads high when excited, especially just after being released into the field after being confined. Also, lowered, "snaking" head movements are considered characteristic stallion behaviour.

112 Ewart, The Penycuik Experiments, 6.

113 Azrek was one of two horses sold to Cecil Rhodes. Archer et al, Crabbet Arabian Stud, 94.

114 Ibidem, 229.

115 Ibidem, 235.

116 Ibidem, 248.

117 A white facial mark.

118 Mulatto was one of the Island of Rhum ponies "lent" to Ewart for experimental purposes by Sir Arthur Cecil (Ewart, The Penycuik Experiments, 3). It should also be noted that Ewart was a believer in the lost horses of the Armada theory, a theory now disproven, leading to the "well-bred" ponies of the Western Highlands: "the late Marquis of Salisbury believed they, not withstanding their colour [probably intended pejoratively, and meaning the dun colour, which is a foundation colour for Highland ponies and indeed many so-called 'unimproved' breeds, ie those ponies closer to their wild or semi-feral ancestors], had Eastern blood in their veins. It has been suggested that they numbered amongst their ancestors horses which escaped from the ill-fated ships of the Spanish Armada. In support of this theory may be mentioned an old tapestry in the House of Lords..." (Ewart, The Penycuik Experiments, 7). Ewart also comments of the Rhum ponies elsewhere: "that in various respects they approach the highest type of horses that has probably ever existed - I mean, of course, the high-caste Arabs" (Ewart, The Penycuik Experiments, 74).

119 Ewart, The Penycuik Experiments, lxv. The overall meaning of this passage is opaque. The meaning of "cross-bred" within the discourse of horse breeding is clear, but it is otherwise impossible to glean what 
Since the appearance of stripes and their length and width are clearly of importance to Ewart in his telegony and reversion experiments, he notes that faint stripes, or "narrow markings that might be mistaken for stripes" in the coat are visible in "highly bred foals with very fine coats" 120 and that he noticed "stripes of this nature...plentifully scattered over a reddish-grey foal out of my flea-bitten New Forest pony by the grey Arab, Benazrek." 121 Benazrek was also mated to a zebra mare with "no difficulty", though she subsequently died that winter. ${ }^{122}$ A photograph of Benazrek is included on page 146 and text on the opposite page further suggests that Wilfrid Blunt was considered an active participant in the "stripes" experiment: "Mr Wilfrid Blunt believes that the offspring of white Arabs are apt to show stripes." 123 Over the page, Ewart provides additional details of the Benazrek/Mulatto pairing: "The sire [Benazrek], bred by the late Earl of Warwick, is a grey Arab, a son of Azrek, for some time a member of Mr. Wilfrid Scawen Blunt's famous stud at Crabbet Park, Sussex. Azrek, also a grey, belonged to the ancient Seglawi Jedran family. Benazrek's dam Shemptes [for Shemse] was also originally a grey; now she is almost white. ${ }^{124} \mathrm{I}$ have had under observation for some time three 'colts' by Benazrek..."125

Finally, Ewart extends his warm thanks to the many people to whom he is indebted (he literally writes of indebtedness), with, at the head of the list, "Lord Arthur Cecil" and "Mr Wilfrid Scawen Blunt."126

Further, Ewart was actively involved in promoting Arab horses for use in "improving" the Highland pony on crofts. In 1898, the "Congested Districts Board of Scotland" was set up with government approval to supply male animals (stallions, bulls, and rams) to crofters in order to "improve" their animals and provide economic support to areas viewed as impoverished. John M. MacDonald notes Ewart's projects involving crossing Highland ponies with zebras, and comments:

I remember seeing those hybrids being exhibited at a Highland show. The professor also claimed to have discovered what he called "The Celtic Pony," which he said was free from callosities on the hind limb and had three varieties of hair on its tail - the short upper hair being shed annually. He gained the confidence of the members of the Congested Districts Board, and on his advice they purchased some Arabian stallions, which were sent to Skye for the use of the crofters and in the hope that they would improve the native breed of ponies. I can recall two of those ponies when they were in use in Skye. They were dark bay, about 14 hands high, and had been, I think, bred in England. They were sparingly taken advantage of by the crofters who considered them too small and fine in the bone and not in the least suited for work on the croft. $[\ldots]$ The crofters were wise in their decision. [...] Those Arab sires were soon discarded by the Congested Districts Board, and years after I encountered them as geldings at local race meetings, where they showed to much better

\footnotetext{
he is attempting to convey in this passage, other than the fact that he considers his horse to be a superior one.

120 Ibidem, lxxvi.

121 Ibidem, lxxvii. When is a stripe not a stripe?

122 Ibidem, 20.

123 Ibidem, 145.

${ }^{124}$ A transformation which happens to all horses that start out as grey, and many horses that are born with black coats.

125 Ewart, The Penycuike Experiments, 147.

126 Ibidem, xciii.
} 
advantage than the crofters' peat carts. After the failure of the Arabs, the next move of the Congested Districts Board was to fall back on the best procurable sires of the native Highland breed. ${ }^{127}$

\section{Conclusion}

In the light of the foregoing evidence of collaboration, with an emphasis on the antiquity, prepotency, and superiority of the Arab horse, I suggest that Ewart's interpretation of the equid remains from Newstead was not wholly objective. There is also little doubt about the fact that there was a strong element of the showman about Ewart's work, and he was an enthusiastic communicator with the press, and capable lobbyist, as noted in various commentaries on his life and work. ${ }^{128}$ Nor should anyone be under any illusion about the lasting effects of his collaboration with Wilfrid Blunt in particular. Its influence can be seen in the report on the Torrs Pony Cap from Galloway, for instance, when the authors argued the case for it being a cap, not a chamfrein, established from head sizes and shapes described in familiar terms:

The effect is ridiculous, and has been achieved only by a marked reduction of the scale of the pony's head in relation to the scale of the head-piece. The fundamental objection to this interpretation is that the head-piece is too small, even for the small type of Celtic pony for which it was designed [here is entered a footnote acknowledging the work at Newstead]. The maximum width of the skull of such a pony occurs at the rear margin of the eye-sockets and is of the order of $18 \mathrm{~cm}$. for a narrow-faced head, and of up to $20 \mathrm{~cm}$. for a more coarsely built animal of the Shetland type. ${ }^{129}$

The footnote reads:

A reliable guide to the type and size of head is given by the skulls of Celtic ponies from Newstead (Curle, Newstead (1911), 362 - 71, pls XCV, XCVI). These belong to animals standing $10-12$ hands high. Sir Cyril Fox in his wellknown reconstruction of a Celtic chariot (Antiq. Journ. xxvii (1947), p. 118, fig. I) assumes a height of $11 \frac{1 / 2}{2}$ hands for the ponies. ${ }^{130}$

Further, giving scientific credence to the antiquity of the Arab horse and its influence meant that not only was the Arabian promoted usefully as a superior breed at a time when horse riding was becoming a leisure activity, rather than a practical necessity, but also the Arab was established as one of the most ancient, unchanging, and original prototypes, if not the prototype. Under Ewart's influence, Arab stallions were promoted to the crofters of the Highlands. It was therefore a ringing endorsement of "The Arabian, the horse of the future" project promoted by Boucaut, Tweedie, the Blunts and others in the late nineteenth century. ${ }^{131}$ This notion encouraged both nations and individuals to find evidence of Arabian horse influence in their own breeds to assert their antiquity and superiority. If evidence was

127 John Donaldson, Higbland Ponies and Some Reminiscences of Higblandmen (Stirling: Eneas Mackay, 1937), 29. While the source of the two Arab stallions is unknown at present, Crabbet Park is not an unlikely suggestion.

${ }^{128}$ Button, "James Cossar Ewart and the Origins of the Animal Breeding Research Department", 11.

129 R.J.C. Atkinson and Stuart Piggott, The Torrs Chamfrein (Oxford: Society of Antiquaries, 1955), 212.

130 Ibidem.

131 James Penn Boucaut, The Arabian, the Horse of the Future (London: Gay and Bird, 1905). 
not there, they were encouraged to "improve" them by the use of the Arab - the original, and therefore the best, a sales pitch that is not unique.

We should not neglect to pay attention to the possible motives of that complex character Wilfrid Blunt in this story. Anti-imperialist yet racist, both perspectives emerging clearly in his writings, ${ }^{132}$ Blunt was no enthusiast for either archaeological excavations or the Romans. As the archetypal English squire with complete control over his Sussex acres and everything that lived on them: "His feelings for Sussex were obsessional, at times irrational. Almost anything could make him indignant. 'I resent these Roman remains in Sussex,' he wrote after hearing of a dig, 'they have no business here, outlandish, imperialistic..."'133

It is a curious coincidence that Sussex, county of the Blunts' Crabbet Stud, was also the location for the Piltdown Man hoax, set in train a year after the publication of the Newstead Report. A skull once again played an important part in establishing proof of one of the obsessions of that era; the discovery of the "missing link" between humans and apes, just as the skull of a single modern "Arab(ian)" was recruited to prove Ewart's "connecting link between modern ponies of the Celtic and Libyan types and the slender-limbed prehistoric races." 134

The tendency to "see Arabians" where there are none may not always be a deliberate attempt to deceive, although it is clear that in at least one other instance, that was the intention, as I have shown elsewhere. ${ }^{135}$ More frequently, it is likely to be a desire to see Arab horses in historical and archaeological contexts because of a pervasive belief that all good horses must have Arab blood in them. Close examination of shared citations within small groups of scholars and enthusiasts, such as those given as examples by Delpeut and Hettema in their paper, often leads back to opinion rather than original documentation or substantial material evidence. ${ }^{136}$ Whatever the motivation, this does a disservice to the Arab horse as well as other horse breeds. Conclusions should be drawn from reflective analysis of the material, rather than wishful thinking.

\section{References}

Archer, Rosemary and James Fleming (eds.). Lady Anne Blunt: Journals and Correspondence 1878 - 1917. Northleach: Alexander Heriot, 1986.

Archer, Rosemary, Colin Pearson and Cecil Covey. The Crabbet Arabian Stud, Its History and Influence. Northleach: Alexander Heriot \& Co, 2002.

Atkinson, R.J.C. and Stuart Piggott. The Torrs Chamfrein. Oxford: Society of Antiquaries, 1955.

Bibby, Miriam A. "Alexander's Arabian: Noble Steed or Fantastic Beast?" In The Materiality of the Horse, eds. Miriam A. Bibby and Brian G. Scott, 175-202. Budapest: Trivent Publishing, 2020.

Boas, F \& H. M. Boas. "The head-forms of the Italians as influenced by heredity and environment.” American Anthropology 15 (1913): 163-188.

\footnotetext{
132 On his way to South America, Blunt bought a black child from a starving woman in the Cape Verde Islands, changed his name from Felipe Pedro da Croz to the single name "Pompey," eventually made him his majordomo. and refused to allow him access to education, commenting: "What is valuable in the black man is that his race is a distinct one...less divergent from the general animal type and so much the happier." Elizabeth Longford, A Pilgrimage of Passion: The Life of Wilfrid Scawen Blunt, , (London: Weidenfeld and Nicolson, 1979), 66.

133 Ibidem, 431.

${ }^{134}$ Curle, The Newstead Report, 366.

${ }_{135}$ Miriam Bibby, "Mist on the Border: Emperor Severus and the Netherby Arabians that never were", in The Liminal Horse, ed. Rena Maguire (Budapest: Trivent Publishing forthcoming title.)

${ }^{136}$ Delpeut and Hettema, Ancient Arabian Horses?, 172.
} 
Boucaut, James Penn. The Arabian, the Horse of the Future. London: Gay and Bird, 1905.

Bower, M.A., M. G. Campana, M. Whitten, C. J. Edwards, H. Jones, E. Barrett, R. Cassidy, R. E. R. Nisbet, E. W. Hill, C. J. Howe, and M. Binns. "The cosmopolitan maternal heritage of the Thoroughbred racehorse breed shows a significant contribution from British and Irish native mares." In Biol. Lett. 7 (2011): 316-320.

Brotton Jerry. The Sale of the Late King's Goods: Charles I \& His Art Collection. London: Macmillan, 2006.

Busby, Debbie and Catrin Rutland. The Horse: a Natural History. London: Ivy Press, 2019.

Button, Clare. "James Cossar Ewart and the Origins of the Animal Breeding Research Department in Edinburgh, 1895 - 1920." In Journal of the History of Biology, Open Access 2017, DOI 10.1007/s10739-017-9500-0.

Cavriani, Carlo. Le razze Gonzaghesche di cavalli nel Mantovano e la loro influenza sul pure sangue inglese. In Rassegna Contemporanea, anno II, 3:4 (1909): 23-24.

Cosgrove, Elissa J., Raheleh Sadeghi, Florencia Schlamp, Heather M. Holl, Mohammad Moradi-Shahrbabak, Seyed Reza Miraei-Ashtiani, Salma Abdalla, Ben Shykind, Mats Troedsson, Monika Stefaniuk-Szmukier, Anil Prabhu, Stefania Bucca, Monika BugnoPoniewierska, Barbara Wallner, Joel Malek, Donald C. Miller, Andrew G. Clark, Douglas F. Antczak \& Samantha A. Brooks. "Genome Diversity and the Origin of the Arabian Horse.” In Scientific Reports (2020) 10:9702, https://doi.org/10.1038/s41598-020-66232.

Curle, James. A Roman Frontier Post and its People. Glasgow: Society of Antiquaries of Scotland, 1911.

Delpeut, Lonneke and Hylke Hettema. "Ancient Arabian horses? Revisiting ancient Egyptian equine imagery." In Current Research in Egyptology 2019: Proceedings of the Twentieth Annual Symposium, ed. Marta Arranz Cárcamo, Raúl Sánchez Casado, Albert Planelles Orozco, Sergio Alarcón Robledo, Jónatan Ortiz García, Patricia Mora Riudavets, 168-182. Oxford: Archaeopress Publishing, 2021.

Donaldson, John. Highland Ponies and Some Reminiscences of Highlandmen. Stirling: Eneas Mackay, 1937.

Ewart, James Cossar. The Penycuike Experiments. London: Adam and Charles Black, 1899.

Fairfax-Blakeborough, Jack. Northern Turf History Vol III. London: J.A. Allen, 1950.

Fairley, John. Racing in Art. London: John Murray, 1990.

- The Art of the Horse. New York: Abbeville Press, 1995.

Głażewska, I. 2010. 'Speculations on the Origin of the Arabian Horse Breed.' In Livestock Science 129 (1) 2010: 49-55.

Hendricks, Bonnie. International Encyclopedia of Horse Breeds. Norman: University of Oklahoma Press, 1995.

Jacobson, Miriam. Barbarous Antiquity: Reorienting the Past in the Poetry of Early Modern England. Pennsylvania: University of Pennsylvania Press, 2014. (Kindle Edition.)

Jobst, Jennifer. "Practical Advice on Equine Care from Jordanus Rufus, c. 1250 CE." In The Materiality of the Horse, eds. Miriam A. Bibby and Brian G. Scott, 35-69. Budapest: Trivent Publishing, 2020.

Lange, Cristoph. 2019. 'The Making and Remaking of the Arabian Horse-From the Arab Bedouin Horse to the Modern Straight Egyptian'. In Horse Breeds and Human Society: Purity, Identity and the making of the Modern Horse, ed. M. Mattfield and K. Guest, 234-50. London: Routledge, 2019.

Lawrence, John. History and Delineation of the Horse. London: Albion Press, 1809.

Leet, Elizabeth. "On Equine Language: Jordanus Rufus and Thirteenth-Century Communicative Horsemanship." In Animal Languages in the Middle Ages, ed. Alison Langdon, 175 - 195. Kentucky: Palgrave Macmillan, 2018. 
Longford, Elizabeth. A Pilgrimage of Passion: The Life of Wilfrid Scawen Blunt. London: Weidenfeld and Nicolson, 1979.

Lowe, Bruce. Breeding Racehorses by the Figure System, ed. William Allison. London: Horace Cox, 1895.

Mackay-Smith, Alexander. Speed and the Thoroughbred, the Complete History. Lanham: The Derrydale Press, 2000.

Markham, Gervase. Discourse of Horsemanship. London: Richard Smith, 1593.

Murray, Amanda. All the King's Horses. London: Robson Books, 2006.

Nash, Richard. "'Honest English Breed': the Thoroughbred as Cultural Metaphor." In The Culture of the Horse: Status, Discipline and Identity in the Early Modern World, eds. Karen Raber and Treva Tucker. New York and London: Palgrave Macmillan, 2005).

Pory, John. A Geographical History of Africa, written in Arabic and Italian by Jobn Leo, a Moor born in Granada and brought up in Barbarie. London: Georg Bishop, 1600.

Preece, Jessie. "A visit to Crabbet Park and the Crabbet collection at the British Natural History Museum." In Versatile Arabian Horse Magazine, Australian Arabian Horse News, June 2015, 26-28. Viewable at: https://issuu.com/vinkpublishing/docs/ahn_june_15/30.

Prior, C.M. The Royal Studs of the Sixteenth and Seventeenth Centuries. (London: Horse and Hound Publications, 1935.

Ramusio, Giovanni Battista. Delle navigationi et viaggi raccolto da m. gio. batt. ramusio, \& con molti vaghi discorsi, da lui in molti luoghi dichiarato, \& illustrato. Nel quale si contengono la Descrittionoe dell'Africa, e del paese del Prete Ianni. Venice: Stamperia de Guinta, 1558.

Andrea Tonni. "The Renaissance Studs of the Gonzagas of Mantua." In The Horse as Cultural Icon: The Real and the Symbolic Horse in the Early Modern World, eds. Peter Edwards, Karl A.E. Enenkel and Elspeth Graham, 261-278. Leiden: Brill, 2012.

Wentworth, Lady Judith. The Authentic Arabian Horse and his Descendants. London: George Allen and Unwin, 1957. 